\title{
Penerapan Problem Based Learning Berbasis Numbered Heads Together: Dampak Hubungan Aktivitas dengan Hasil Belajar
}

\author{
Aminah Khoirunisa ${ }^{1}$, Mukhlis Rohmadi ${ }^{2}$, Hadma Yuliani $^{3}$ \\ ${ }^{1,2,3}$ Prodi Tadris Fisika, FMIPA, Institut Agama Islam Negeri (IAIN) Palangka Raya, Jl. \\ G.Obos, Komplek Islamic Centre Palangka Raya, 73112 \\ E-mail: Aminahkhairunisa97@gmail.com
}

\begin{tabular}{|c|c|}
\hline Article Info & lbstract \\
\hline $\begin{array}{l}\text { Article History } \\
\text { Received: Mei } 2020 \\
\text { Revised: December } 2020 \\
\text { Published: December } 2020\end{array}$ & \multirow{2}{*}{$\begin{array}{l}\text { The study aims to determine the significant difference between the learning } \\
\text { outcomes of students 'physics before and after and the significant relationship } \\
\text { between students ' activities and the results of student physics learning after } \\
\text { applying the problem based learning model numbered heads together. Type of } \\
\text { research conducted is quasi experimental design is one group Pretest-posttest } \\
\text { design. Sampling using saturated sampling. The research Data is obtained by } \\
\text { using the observation sheet of student activity and the test result is description } \\
\text { of the explanation. Based on data analysis results The conclusion that there is } \\
\text { a significant difference between the results of learning before and after with a } \\
\text { significance value of } 0.000<0.05 \text { and there is a significant relationship } \\
\text { between student activity with the results of student physics learning after } \\
\text { applied model based learning numbered heads together with significance } \\
\text { value } 0.028<0.05 \text {. }\end{array}$} \\
\hline $\begin{array}{l}\text { Keywords } \\
\text { Problem Based LC } \\
\text { Numbered Heads } T \\
\text { student activity, } \\
\text { results }\end{array}$ & \\
\hline Informasi Artikel & Abstrak \\
\hline $\begin{array}{l}\text { Sejarah Artikel } \\
\text { Diterima: Mei } 2020 \\
\text { Direvisi: Desember } 2020 \\
\text { Dipublikasi: Desember } 2020\end{array}$ & \multirow{2}{*}{$\begin{array}{l}\text { Penelitian ini bertujuan untuk mengetahui perbedaan yang signifikan antara } \\
\text { hasil belajar fisika siswa sebelum dan sesudah dan hubungan yang signifikan } \\
\text { antara aktivitas siswa dengan hasil belajar fisika siswa setelah diterapkan } \\
\text { model problem based learning berbasis numbered heads together. Jenis } \\
\text { penelitian yang dilakukan adalah quasi experimental design yaitu one group } \\
\text { pretest-posttest design. Pengambilan sampel menggunakan sampling jenuh. } \\
\text { Data hasil penelitian diperoleh dengan menggunakan lembar observasi } \\
\text { aktivitas siswa dan tes hasil belajar berupa soal uraian. Berdasarkan hasil } \\
\text { analisis data diperoleh kesimpulan bahwa terdapat perbedaan yang signifikan } \\
\text { antara hasil belajar sebelum dan sesudah dengan nilai signifikansi } 0,000<0,05 \\
\text { dan terdapat hubungan yang signifikan antara aktivitas siswa dengan hasil } \\
\text { belajar fisika siswa setelah diterapkan model problem based learning berbasis } \\
\text { numbered heads together dengan nilai signifikansi } 0,028<0,05 \text {. }\end{array}$} \\
\hline $\begin{array}{l}\text { Kata kunci } \\
\text { Problem Based Learning, } \\
\text { Numbered Heads Together, } \\
\text { Aktivitas Siswa, Hasil } \\
\text { belajar. }\end{array}$ & \\
\hline
\end{tabular}

Sitasi: Khoirunisa, A., Rohmadi. M., \& Yuliani, H. (2020). Penerapan Problem Based Learning Berbasis Numbered Heads Together: Dampak Hubungan Aktivitas dengan Hasil Belajar. Kappa Journal. 4(2), 165-171.

\section{PENDAHULUAN}

Pembelajaran merupakan proses interaksi antara guru dan siswa yang dalam proses tersebut terdapat upaya untuk meningkatkan kualitas diri siswa menjadi lebih baik dari sebelumnya (Priansa, 2017). Keberhasilan dalam pembelajaran tentunya tidak terlepas dari kemampuan guru dalam mengembangkan model-model pembelajaran. Selain berorientasi pada keterlibatan siswa dalam proses belajar, model pembelajaran pada dasarnya dapat dijadikan sebagai salah satu untuk menciptakan kondisi pembelajaran yang memungkinkan siswa dapat belajar secara aktif dan menyenangkan. 
Berdasarkan hasil observasi yang telah dilakukan di MA Darul Ulum Palangka Raya khususnya pada kelas XI IPA pada tanggal 17 januari 2019, ditemukan bahwa selama ini proses pembelajaran yang terjadi di kelas masih bersifat pasif. Guru terlihat mendominasi pembelajaran dengan aktif menjabarkan persamaan matematis. Hal ini menyebabkan siswa cenderung diam dan kurang memperhatikan saat pembelajaran berlangsung. Hal ini tentunya membuat siswa mudah merasa bosan dalam melaksanakan proses belajar, terlebih lagi pembelajaran tersebut dilaksanakan pada jam siang.

Hasil penyebaran angket berupa lembar pertanyaan siswa di kelas XI IPA MA Darul Ulum Palangka Raya yang menunjukkan siswa cenderung kesulitan dalam memahami materi fisika yang disampaikan oleh guru. Banyaknya materi fisika yang memuat rumus menuntut siswa untuk menghafal. Tentu kondisi pembelajaran yang seperti ini akan membuat siswa menjadi kurang aktif sehingga aktivitas dan hasil belajar fisika siswapun menjadi rendah. Hal ini dibuktikan dengan masih adanya siswa yang mendapatkan nilai kurang dari 70 atau di bawah KKM (Kriteria Ketuntasan Minimal) dengan nilai rata-rata 65.

Mengenai permasalahan di atas, perlu adanya upaya dengan menciptakan situasi dan kondisi pembelajaran yang bervariasi. pembelajaran yang bervariasi sangat penting bagi terlaksananya pencapaian tujuan pembelajaran (Suprihatiningrum, 2014). Salah satu model pembelajaran saat ini yang direkomendasikan para ahli dan juga dianggap relevan dengan implementasi kurikulum 2013 untuk mengembangkan kompetensi siswa adalah model Problem Based Learning. Problem Based Learning merupakan proses pembelajaran yang menghadapkan siswa dengan permasalahan nyata. Siswa dihadapkan pada beberapa permasalahan yang terjadi di lingkungan sekitar, sehingga siswa belajar tidak hanya belajar mengenai pengetahuan tetapi juga merasakan dan mengalami sendiri. (Hartono, 2013). Problem Based Learning dipadukan dengan Power Point juga memberikan pengaruh terhadap hasil belajar fisika (Wajdi, 2018).

Dari penelitian terdahulu yang dilakukan Baksir et al (2017) mengenai Problem Based Learning, terdapat kelebihan yakni model ini dapat mendorong siswa untuk lebih aktif dalam belajar. Siswa diarahkan dapat membangun pengetahuannya sendiri melalui berbagai percobaan dan cara pemecahan masalahnya. Di samping memiliki kelebihan, Problem Based Learning ini juga memiliki kekurangan yakni dapat dilihat pada penelitian terdahulu yang dilakukan Rerung et al (2017), dimana siswa yang memiliki kemampuan rendah tentu akan merasa kesulitan dalam menerima materi pelajaran. Untuk menutupi kekurangan dari model Problem Based Learning ini, maka digunakan upaya pembelajaran kooperatif yakni Numbered Heads Together.

Menurut Abidin (2014), model kooperatif biasanya digunakan secara khusus dalam proses pembelajaran, namun dalam kurikulum 2013 model pembelajaran kooperatif dapat menjadi wadah bagi model-model yang lain. Hal ini diperkuat dengan beberapa hasil studi penelitian sebelumnya yang dilakukan yakni model pembelajaran kooperatif Jigsaw dan Two Stay Two Stray secara signifikan meningkatkan hasil belajar (Anwar et al, 2018). Penelitian lain yang dilakukan oleh Nurul Hidayah (2016) yang menunjukkan bahwa model Problem Based Learning dipadu Numbered Heads Together mampu meningkatkan keaktifan dan hasil belajar siswa.

Dengan melihat hasil penelitian di atas, ditemukan adannya kecocokan dari Problem Based Learning dengan Numbered Heads Together. Penerapan model Problem Based Learning berbasis Numbered Heads Together yang menarik ini, diharapkan mampu mengurangi kesulitan belajar siswa terhadap pembelajaran di kelas. Hal inilah yang melatar belakangi peneliti sehingga tertarik melakukan penelitian, terutama dalam pembelajaran fisika.

Berdasarkan uraian latar belakang dan permasalahan di atas, diangkat judul dalam penelitian ini yaitu penerapan Problem Based Learning berbasis Numbered Heads Together terhadap aktivitas dan hasil belajar fisika siswa". Adapun tujuan yang ingin dicapai dalam 
penelitian ini adalah: (1) Untuk mengetahui perbedaan yang signifikan antara hasil belajar fisika siswa sebelum dan sesudah. (2) Untuk mengetahui hubungan yang signifikan antara aktivitas dengan hasil belajar fisika siswa.

\section{METODE}

Jenis penelitian yang dilaksanakan adalah eksperimen semu (quasi experimental design) dengan tipe "one groups pretest-posttest design". Desain ini dapat digambarkan sebagai berikut (Sugiyono, 2012):

Tabel 1: Desain Satu Kelompok Pretest- Posttest

\begin{tabular}{cccc}
\hline \multirow{2}{*}{$\begin{array}{c}\text { Satu } \\
\text { kelompok }\end{array}$} & Pretest & Perlakuan & Posttest \\
\cline { 2 - 4 } & $\mathrm{O}_{1}$ & $X$ & $\mathrm{O}_{2}$ \\
\hline
\end{tabular}

Penelitian ini berlokasi di MA Darul Ulum Palangka Raya yang berada di jalan Dr. Murjani gang sari nomor 45, pahandut Kota Palangka Raya Propinsi Kalimantan Tengah. Penelitian ini dilaksanakan di kelas XI IPA semester I (Ganjil) tahun pelajaran 2019/2020.

Teknik pengumpulan data dilakukan dengan menggunakan instrumen penelitian yaitu tes hasil belajar fisika siswa dan lembar observasi pengamatan aktivitas siswa. Tes yang digunakan berupa soal uraian yang telah diuji keabsahan datanya. Uji keabsahan data meliputi validitas, reliabilitas, daya pembeda dan tingkat kesukaran.

Uji-t dilakukan untuk mengetahui perbedaan hasil belajar fisika siswa sebelum dan sesudah pembelajaran. Rumus uji-t, yaitu (Sugiyono, 2015):

$$
\mathrm{t}=\frac{\overline{\mathrm{x}}-\mu \mathrm{o}}{\frac{\mathrm{s}}{\sqrt{\mathrm{n}}}}
$$

Uji korelasi dilakukan untuk mengetahui hubungan antara aktivitas dan hasil belajar fisika siswa. Rumus uji korelasi yaitu Pearson Product Moment (Siregar, 2014).

$$
\mathrm{r}=\frac{\mathrm{n}\left(\Sigma_{\mathrm{xy}}\right)-\left(\Sigma_{\mathrm{x}} \Sigma_{\mathrm{y}}\right)}{\sqrt{\left[\mathrm{n} \Sigma \mathrm{x}^{2}-(\Sigma \mathrm{x})^{2}\right]\left[\mathrm{n} \Sigma \mathrm{y}^{2}-(\Sigma \mathrm{y})^{2}\right]}}
$$

\section{HASIL DAN PEMBAHASAN}

\section{Hasil Belajar}

Berdasarkan data hasil penelitian berupa hasil belajar fisika yang diperoleh dari nilai rata-rata Pretest, Posttest, Gain dan $N$-gain tes hasil belajar. Hasil analisis data peningkatan hasil belajar fisika siswa melalui uji $N$-gain diperlihatkan pada tabel 2 berikut.

Tabel 2: Nilai rata-rata Pretest, Posttest, Gain dan N-gain hasil belajar

\begin{tabular}{ccccc}
\hline $\mathrm{N}$ & \multicolumn{4}{c}{ Rata-rata } \\
\cline { 2 - 5 } & Pretest & Posttest & Gain & $N$-gain \\
\hline 29 & 37,6 & 74,2 & 34,6 & 0,5 \\
\hline
\end{tabular}

Tabel 2 menunjukkan rekapitulasi presentase nilai rata-rata Pretest dan Posttest sebesar 37,6 dan 74,2. Nilai rata-rata Gain sebesar 34,6 dan nilai rata-rata $N$-gain diperoleh sebesar 0,5 dengan kategori cukup.

Uji prasyarat analisis menggunakan SPSS versi 16.0 for windows dengan taraf signifikansi sebesar 0,05. Uji normalitas dan uji homogenitas dilakukan sebelum uji beda.

Hasil analisis perbedaan hasil belajar fisika siswa diperlihatkan pada tabel 3 berikut. 
Tabel 3: Hasil Uji Beda Hasil Belajar Fisika Siswa

\begin{tabular}{ccc}
\hline $\begin{array}{c}\text { Sumber } \\
\text { Data }\end{array}$ & Sig. & Keterangan \\
\hline $\begin{array}{c}\text { Pretest- } \\
\text { Posttest }\end{array}$ & 0,000 & $\begin{array}{c}\text { Ada perbedaan } \\
\text { signifikan }\end{array}$ \\
\hline
\end{tabular}

Tabel 3 menunjukkan hasil uji beda (One Sample T-test) dan diperoleh nilai signifikansi $<0,05$ yang berarti bahwa terdapat perbedaan yang signifikan hasil belajar fisika siswa sebelum dan sesudah diberikan perlakuan dengan menggunakan model Problem Based Learning berbasis Numbered Heads Together.

Adapun hasil analisis data Pretest dan Posttest hasil belajar fisika siswa pada tiap nomor soal disajikan pada gambar 1 berikut.

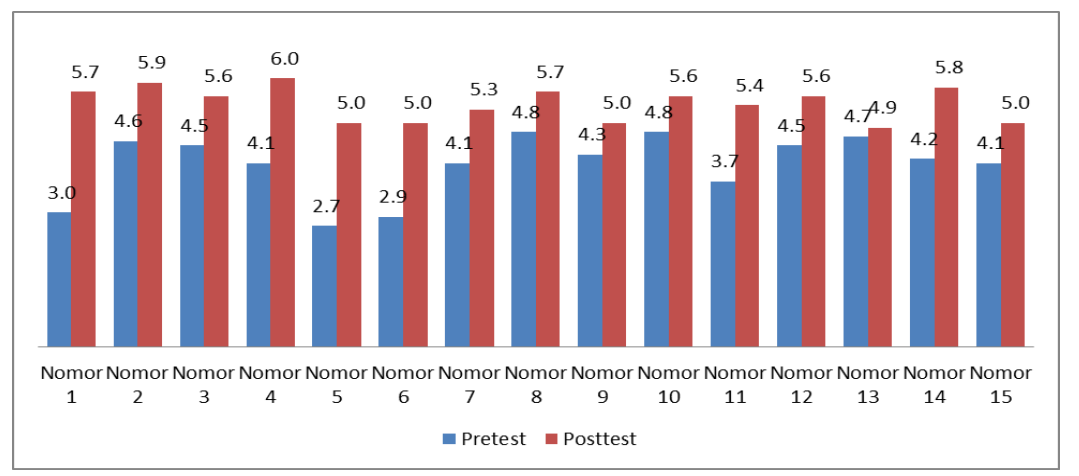

Gambar 1 Nilai rata-rata Pretest dan Posttest pada tiap nomor soal

Gambar 1 menunjukkan hasil belajar fisika siswa terlihat mengalami peningkatan pada tiap indikatornya. Terlihat hasil Posttest terendah terdapat pada nomor 5, 6, 9, dan 15 yaitu 5,0 sedangkan hasil Posttest tertinggi terdapat pada nomor 4 yaitu 6,0. Hal ini dikarenakan, pada saat kegiatan Pretest siswa sama sekali belum memahami dan mengetahui materi fluida statis sehingga nilai rata-rata Pretest hasil belajar fisika siswa rendah.

Perbedaan hasil belajar fisika siswa juga dipengaruhi beberapa faktor sebagaimana yang dikemukakan oleh Munadi yang meliputi faktor internal dan eksternal. Faktor internal secara umum meliputi kondisi kesehatan, minat, motivasi dan daya nalar siswa itu sendiri. Faktor eksternal secara umum meliputi faktor lingkungan dan faktor instrumental berupa kurikulum, sarana dan guru (Rusman, 2017).

Hal ini sejalur dengan penelitian yang dilakukan oleh Syahdani (2014) bahwa terdapat perbedaan antara hasil belajar sebelum dan sesudah pembelajaran kooperatif tipe Numbered Heads Together dengan model Problem Based Learning. Siswa tidak hanya diajak untuk berkelompok dan bekerja sama untuk menyelesaikan masalah yang diberikan tetapi juga diarahkan untuk membangun sendiri pengetahuannya.

\section{Aktivitas}

Hasil analisis terhadap aktivitas siswa pada setiap pelaksanaan RPP disajikan pada tabel 9 berikut.

Tabel 9: Aktivitas Siswa

\begin{tabular}{ccccc}
\hline Data & \multicolumn{3}{c}{ Persentase (\%) } & Rata- \\
\cline { 2 - 4 } & RPP & RPP & RPP & rata \\
I & II & III & \\
\hline Aktivitas & 69,7 & 72,8 & 78,8 & 73,7 \\
Siswa & & & & \\
\hline
\end{tabular}


Tabel 9 di atas menunjukkan aktivitas siswa secara keseluruhan didapat persentase ratarata penilaian sebesar $73,7 \%$ dengan kategori baik. Adapun rekapitulasi nilai rata-rata aktivitas siswa pada tiap indikator disajikan pada gambar 2 berikut.

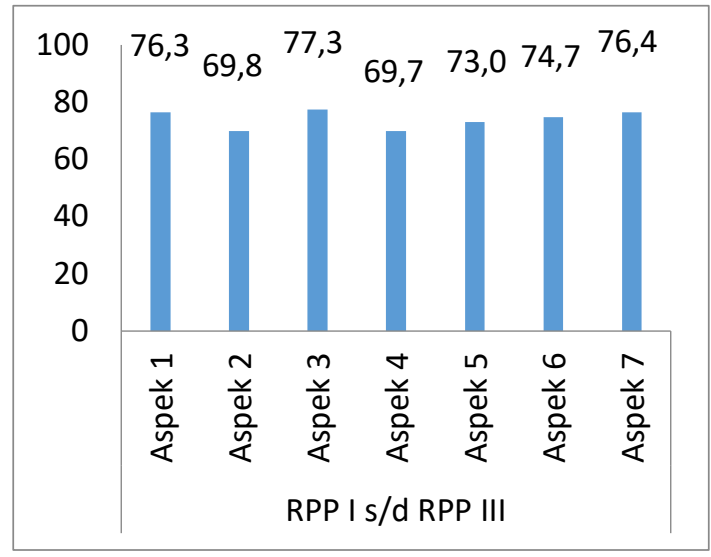

Gambar 2 Aktivitas Siswa Pada Tiap Indikator

Grafik 1 menunjukkan mayoritas aspek aktivitas siswa pada semua indikator berada pada kategori baik dengan nilai indikator aktivitas siswa berturut-turut sebesar 76,3\%, $69,8 \%, 77,3 \%, 69,7 \%, 73,0 \%, 74,7 \%, 76,4 \%$. Aktivitas siswa terendah terjadi pada indikator 4 yakni Mental Activities dengan nilai 69,7\% dan aktivitas siswa tertinggi terjadi pada indikator 3 yakni Writing Activities dengan nilai 77,3\%.

\section{Hubungan Aktivitas Siswa Dengan Hasil Belajar Fisika}

Adapun hasil analisis data hubungan aktivitas siswa dengan hasil belajar fisika siswa disajikan pada tabel 4 berikut.

Tabel 4: Hubungan Aktivitas Siswa Dengan hasil belajar fisika siswa

\begin{tabular}{|c|c|c|c|}
\hline $\begin{array}{c}\text { Sumber } \\
\text { Data }\end{array}$ & $\mathrm{N}$ & Sig & Ket \\
\hline Aktivitas & \multirow[t]{2}{*}{29} & \multirow[t]{2}{*}{0,028} & \multirow{2}{*}{$\begin{array}{l}\text { Terdapat } \\
\text { hubungan } \\
\text { yang } \\
\text { signifikan }\end{array}$} \\
\hline $\begin{array}{c}\text { Hasil } \\
\text { belajar } \\
\text { Fisika }\end{array}$ & & & \\
\hline
\end{tabular}

Tabel 4 menunjukkan bahwa antara aktivitas siswa dan hasil belajar fisika siswa terdapat hubungan yang signifikan antara aktivitas siswa dengan hasil belajar fisika siswa setelah diterapkan model Problem Based Learning berbasis Numbered Heads Together dengan nilai signifikansi $<0,05$. Hal ini dikarenakan nilai aktivitas siswa lebih tinggi dibandingkan dengan nilai hasil belajar fisika siswa. Tinggi rendahnya aktivitas yang dilakukan siswa akan sangat berpengaruh terhadap hasil belajar yang diperoleh. Bila semakin tinggi tingkat keaktifan masing-masing siswa dalam mengikuti pembelajaran maka semakin baik pula hasil belajarnya. Begitu juga sebaliknya, semakin rendah tingkat keaktifan masingmasing siswa dalam pembelajaran maka hasil belajarnya juga akan rendah.

Seiring bertambahnya keaktifan siswa, kemauan siswa untuk mencari informasi yang berkaitan dengan materi juga turut bertambah (Ernawati, 2017). Hal ini tidak terlepas dari peran seorang guru dalam melaksanakan pembelajaran. Seperti yang dikemukakan oleh Sanjaya, peran guru sangat penting dalam melakukan usaha dalam membangkitkan motivasi agar keaktifan siswa dalam kegiatan pembelajaran menjadi lebih baik, sehingga hasil belajar yang diperoleh siswa menjadi lebih maksimal dan sesuai dengan tujuan pembelajaran. 


\section{KESIMPULAN}

Berdasarkan hasil penelitian dan analisis data yang telah dilakukan, dapat diambil kesimpulan. (1) Terdapat perbedaan yang signifikan antara hasil belajar fisika siswa sebelum dan sesudah penerapan model Problem Based Learning berbasis Numbered Heads Together dengan nilai $0,000<0,05$. (2) Terdapat hubungan yang signifikan antara aktivitas siswa dengan hasil belajar fisika siswa dengan nilai $0,028<0,05$.

\section{SARAN}

Penerapan Problem Based Learning berbasis Numbered Heads Together dan dampaknya terhadap aktivitas dan hasil belajar siswa dapat diadakan penelitian lebih lanjut dengan materi fisika lainnya yang lebih kompleks

\section{UCAPAN TERIMA KASIH}

Ucapan terima kasih terutama ditujukan kepada program studi tadris fisika yang telah memberi kesempatan dalam penelitian ini.

\section{DAFTAR PUSTAKA}

Abidin, Yunus. 2014. Desain Sistem Pembelajaran Dalam Konteks Kurikulum 2013. Bandung: PT Refika Aditama

Anwar, Miftah; Yuliani, Hadma, Fatmawati, Sri. 2018. Perbandingan Model Pembelajaran Kooperatif Tipe Jigsaw dan Tipe Two stay Two Stray Terhadap Hasil Belajar Siswa Pada Materi Elastisitas. Edu Fisika Jurnal Pendidikan Fisika, Vol 3 (2).

Baksir, Elda Lestari; Mayub, Afrizal, Putri ,Desy Hanisa. 2017. Peningkatan Aktivitas Dan Hasil Belajar Siswa Serta Kemampuan Pemecahan Masalah Melalui Model Problem Based Learning Pada Konsep Cahaya Di Kelas VIII.E SMPN 6 Kota Bengkulu. Jurnal Pembelajaran Fisika Universitas Bengkulu, Vol.1 (1).

Ernawati. 2017. Pengaruh Pembelajaran Berbasis Masalah Terhadap Hasil Belajar IPA Ditinjau Dari Kemampuan Berfikir Kritis. Jurnal Ilmiah Pendidikan IPA, Vol. 4 (1).

Hidayah, Nurul. 2016. Pengaruh Model Pembelajaran Problem Based Learning (PBL) Dipadukan Dengan Numbered Heads Together (NHT) Terhadap Keaktifan Dan Hasil Belajar Siswa Kelas VII SMP PGRI 1 Kediri Pokok Bahasan Pencemaran Lingkungan. Skripsi: Universitas Nusantara PGRI Kediri.

Hartono, Rudi. 2013. Ragam Model Mengajar yang Mudah diterima Murid. Yogyakarta: Diva Press

Priansa, Donni Juni. 2017. Pengembagan strategi dan Model Pembelajaran. Bandung: CV Pustaka Setia

Rerung, Nensy; Sinon, Iriwi L.S, Widyaningsih, Sri Wahyu. 2017. Penerapan Model Pembelajaran Problem Based Learning (PBL) Untuk Meningkatkan Hasil Belajar Peserta Didik SMA Pada Materi Usaha Dan Energi. Jurnal Ilmiah Pendidikan Fisika Al-Biruni UIN Raden Intan Lampung, 47-55.

Rusman. 2017. Belajar dan Pembelajaran: Berorientasi Standar Proses Pendidikan. Jakarta: Kencana

Sugiyono. 2012. Metode Penelitian Administrasi. Bandung: Alfabeta

Sugiyono. 2015. Metode Penelitian \& Pengembangan Research and Development. Bandung: Alfabeta

Siregar, 2014. Statistik Parametrik Untuk Penelitian Kuantitatif. Jakarta: Bumi Aksara

Syahdani, Ferdi. 2014. Perbandingan Hasil Belajar Siswa Menggunakan Model Pembelajaran Kooperatif Tipe NHT Dikombinasikan Dengan Model Pembelajaran PBL Dengan Model Pembelajaran Konvensional di MAN 1 Model Kota Bengkulu. Skripsi: Universitas Bengkulu 
Suprihatiningrum, Jamil. 2014. Strategi pembelajaran. Yogyakarta: Ar-Ruzz Media

Wajdi, Badrul. 2018. Penerapan Model Pembelajaran Problem Based Learning (PBL) Menggunakan Media Power Point Pada Pembelajaran Fisika. Kappa Journal Pendidikan Fisika, Vol. 11 